Table 1. FAwN/100 HIND RATIOS FOR RED DEER (Cervus elaphus) FROM FIVE NEW ZeALAND AREAS

Area Total Fawns/ animals 100 Hinds Approx. 90 per cent Central North Island Nelson-Marlborough Canterbury South Westland All areas

$\begin{array}{r}13 \\ 2 \\ 2 \\ 2 \\ \hline\end{array}$
28
70
39
47
35 \pm .8
\pm 13.9 $9 \cdot 6$
$\pm 10 \cdot 1$ $\pm 13 \cdot 5$

Corrected $\chi^{2}$ (ref. 1) to test differences between the areas was 20.62 with a probability of a greater value 0.0004 . Approximate 90 per cen confldence limits were calculated using the formula

$$
\frac{100 F}{H} \pm\left(100 \sqrt{\left.\frac{(\vec{F}+H) F}{H^{3}}\right)} 1 \cdot 6449\right. \text {. }
$$

for two consecutive years. Three of the five areas showed no significant difference between fawn/hind ratios taken in 1952 and 1953 . Values for the three areas were: Central North Island, 27/100-31/100 $\left(\chi^{2}=0.023\right)$; Nelson-Marlborough, 67/100-75/100 $\left(\chi^{2}=0 \cdot 228\right)$; and Southern Lakes, 48/100-47/100 $\left(\chi^{2}=0.00015\right)$.

Southern Lakes, South Westland, Canterbury and Central North Island habitats include most of the deer population in New Zealand. Fawn/hind ratios from these four areas combined $(41( \pm 4) / 100)$ correspond closely to those recorded by Alex-Hansen ${ }^{3}$ from Jutland $(38 \cdot 5 / 100)$, near the northern limit of the range of the European red deer, and are significantly less $\left(\chi^{2}=6 \cdot 84\right)$ than those ratios of $60 / 100$ recorded from Scotland and Germany by Darling ${ }^{4}$ and Müller-Using ${ }^{5}$ respectively.

Grateful acknowledgment is made to those Government shooters who co-operated in recording results of unselective shooting to make these data available. This work was done while I was employed by the Department of Internal Affairs. The formula for approximate 90 per cent confidence limits was supplied by the Applied Mathematics Laboratory, Department of Scientific and Industrial Research, New Zealand.

\section{Thane RnNey}

New Zealand Forest Service, Wellington, New Zealand. Oct. 21.

'Fisher, R. A., "Statistical Methods for Research Workers" (Oliver and Boyd, 1950)

${ }^{2}$ Riney, T., N.Z.J. Sci. and Tech., 36, B, 5, 429 (1955).

Alex-Hansen, Borge, Dansk Jagttidende, 67, 170 (1950).

"Darling, F. F., "A Herd of Red Deer. A Study in Animal Behaviour" (Oxford, i937).

"Müller-Using, D., "Grundlagen moderner Jagdwirtschaft"' (Krogers Verlagsanstalt, 1949) Review by Westerskov, K., $J$. Wild Mgt., 17, 84 (1953).

\section{The Reniform Nematode in the Gold Coast}

THE reniform nematode (Rotylenchulus reniformis) was first described as an obligate parasite on the roots of many plants in Hawaii ${ }^{1}$, and a list of sixtyfive hosts was given by Linford and Yap ${ }^{2}$. Subsequent records ${ }^{3-5}$ have added a further five hosts from the United States.

The occurrence of the reniform nematode has now been noted on a number of hosts at three sites in the Gold Coast, West Africa.

Plants on which this nematode has been found capable of egg production in the Gold Coast are : Amaranthus spinosus L.*, Citrus limon Burm. f.*, Crotalaria juncea L., Crotalaria striata D.C., Daucus carota L. var. sativa D.C., Glycine max Merr.*, Hibiscus esculentus L., Ipomoea batatus L.*, Lycopersicon esculentum Mill., Manihot esculenta Grantz.*, Nicotiana tabacum L., Persea americana Mill.*, Poinciana pulcherrima L.*, Solanum melongena L. var. esculentum, Sorghum vulgare Pers., Synedrella nodiflora Gaertn.*, Vigna sinensis Endl., and Zea mays L. Those marked with an asterisk are new host records for the reniform nematode.

Life-history studies suggest that the West African forms have a shorter life-cycle than those described by Linford and Oliveira1. Soya grown from seed in soil infested with Rotylenchulus contained swollen forms after four days, mature females with gelatinous matrix after seven days; egg-laying commenced at ten days, and, fifteen days after sowing, secondgeneration larvæ were hatching within the eggmasses.

All three sites were old centres of European cultivation within fifteen miles of the capital, Accra, so it is not possible to say whether the reniform nematode is indigenous to the Gold Coast. A more detailed account will be given elsewhere at a later date.

I wish to thank Dr. J. B. Goodey, Nematology Department, Rothamsted, and Dr. S. A. Sher, Division of Plant Nematology, Riverside, California, for help and advice.

Faculty of Agriculture,

\section{F. C. PeacoCK}

University College of the Gold Coast, Achimota.

Nov. 16.

${ }^{1}$ Linford and Oliveira, Proc. Helm. Soc. Wash., 7, (1), 35 (1940).

2 Linford and Yap, Proc. Helm. Soc. Wash. 7 (1), 42 (1940).

${ }^{3}$ Smith and Taylor, Phytopath., 31 (8), 771 (1941).

- Steiner, Phytopath., 37 (6), 441 (1947).

'Steiner, Proc. Soil Sci. Soc. Fla., 4B, 72 (1949).

\section{Regulation of Outbreeding in Field Beans (Vicia faba)}

IT has been reported that field beans show about 30 per cent of cross-fertilization in eastern England ${ }^{1}$, and rather more in eastern France and Germany ${ }^{2}$. In the course of some pollination experiments at the Plant Breeding Institute, evidence has been obtained of a natural regulating mechanism which stabilizes this breeding structure.

The plants studied came from commercial seed, inbred lines, and $F_{1}$ hybrids, and were grown in an insect-proof glasshouse. Several self- and crossfertilization treatments were applied, and the results of three of these are set out in Table 1, expressed as the mean number of seeds obtained per flower treated.

It can be seen that, on inbreeding, the ability to set seed without some manipulation of the flower was progressively lost. In most cases it was immaterial whether self- or cross-pollen was applied, except in the more advanced inbreds, where cross-pollen was more effective, possibly indicating some degree of self-incompatibility in this group. On hybridization,

\begin{tabular}{|c|c|c|}
\hline Group & & Treatment \\
\hline Commercial sample & 0.56 & $2.97 \quad 2.89 \pm 0.266$ \\
\hline Second-generation inbreds & 0.27 & $\overline{2} \cdot 13 \quad 1.87 \pm 0.158$ \\
\hline Fourth-generation inbreds & 0.04 & $1.42 \quad 2 \cdot 14 \pm 0.123$ \\
\hline $\begin{array}{l}F \text {, hybrids between third-generation } \\
\text { inbreds }\end{array}$ & $1 \cdot 36$ & $1.98 \quad 2.09 \pm 0.133$ \\
\hline
\end{tabular}

